\title{
Can motorcycle riding in Australia really be that thermally stressful?
}

\author{
Liz de Rome, Elizabeth A Taylor, Rodney J Croft, Julie Brown, Nigel AS Taylor ${ }^{*}$ \\ From 15th International Conference on Environmental Ergonomics (ICEE XV) \\ Portsmouth, UK. 28 June - 3 July 2015
}

\begin{abstract}
Introduction
Personal protective clothing and equipment, when used during moderate to heavy workloads, can push individuals to the limits of physiological regulation. What is less certain is the physiological strain imposed by appropriately protective ensembles when riding a motorcycle, and whether or not one need even consider the impact of that strain. Nevertheless, evidence indicates that thermal discomfort is a key disincentive to the wearing of motorcycle protective clothing in hot weather. Therefore, the purpose of this investigation was to quantify thermal and cardiovascular strain during a simulated urban, motorcycle ride, conducted under laboratory conditions.
\end{abstract}

\section{Methods}

Twelve males were investigated on four occasions across three thermal environments: $25^{\circ} \mathrm{C}$ (water vapour pressure $1.3 \mathrm{kPa}), 30^{\circ} \mathrm{C}(1.7 \mathrm{kPa})$ and $35^{\circ} \mathrm{C}(2.25 \mathrm{kPa})$. Each trial was comprised of three, 30-min stages: 25 min cycling $(30 \mathrm{~W})$ plus 5 min rest. Heart rates, auditory-canal and mean skin temperatures were measured. Subjects were also exposed to an overhead radiant heat load and a $30 \mathrm{~km} \cdot \mathrm{h}^{-1}$ headwind. Clothing was modified between full accident protection (helmet, jacket, trousers, gloves, boots; ventilation ports closed) and an unprotected state (helmet, gloves, boots, jeans, long-sleeve t-shirt), with both conditions tested at $25^{\circ} \mathrm{C}$, and the full protective ensemble also investigated at $30^{\circ} \mathrm{C}$ and $35^{\circ} \mathrm{C}$.

\section{Results}

Increasing rider protection at $25{ }^{\circ} \mathrm{C}$ did not modify auditory-canal temperature $(P>0.05)$, but mean skin

\footnotetext{
* Correspondence: nigel_taylor@uow.edu.au

Neuroscience Research Australia, Sydney and the Centre for Human and Applied Physiology, School of Medicine, University of Wollongong,
} Wollongong, Australia

temperatures $\left(2^{\circ} \mathrm{C}\right)$ and steady-state heart rates were increased (12 beats. $\mathrm{min}^{-1}$; both $\left.P<0.05\right)$ with increased protection. Increments in air temperature reduced the skin-air temperature gradient $(P<0.05)$ and dry heat loss. Consequently, at $35{ }^{\circ} \mathrm{C}$, auditory-canal temperature rose at $0.02^{\circ} \mathrm{C} \cdot \mathrm{min}^{-1}$ (SD 0.005), deviating from all trials $(P<0.05)$, and the thresholds for moderate $\left(>38.5{ }^{\circ} \mathrm{C}\right)$ and profound hyperthermia $\left(>40.0^{\circ} \mathrm{C}\right)$ were predicted to occur within $105 \mathrm{~min}$ (SD 20.6) and $180 \mathrm{~min}$ (SD 33.0). The latter might eventuate in $\sim 10 \mathrm{~h}$ at $30{ }^{\circ} \mathrm{C}$, but would not occur at $25{ }^{\circ} \mathrm{C}$. Thermal discomfort increased sequentially in the $35^{\circ} \mathrm{C}$ trial, averaging between "uncomfortable" and "very uncomfortable".

\section{Discussion}

The principal outcomes from this experiment were that, within air temperatures that approximated deep-body temperature, as may be encountered during an Australian summer, urban motorcyclists would be likely to approach profound hyperthermia and potentially debilitating central cardiovascular strain within $3 \mathrm{~h}$, and earlier in sedentary riders. However, at air temperatures of $25^{\circ}$ and $30{ }^{\circ} \mathrm{C}$, neither of those outcomes would be likely. What remains uncertain is whether or not the level of physiological strain encountered at $35^{\circ} \mathrm{C}$ would have an adverse impact upon cognitive function, perhaps through reducing cerebral blood flow, which may, in turn, elevate the risk of motorcycle accidents. This possibility forms the basis of ongoing research.

\section{Conclusion}

This experiment was designed to evaluate the physiological significance of motorcycle impact-protective ensembles under close to worst-case conditions. The outcomes indicate that greater design attention is required to enhance dry and evaporative heat dissipation from clothing 
intended for summer use in hotter climates, but without compromising injury protection.

Published: 14 September 2015

doi:10.1186/2046-7648-4-S1-A20

Cite this article as: de Rome et al: Can motorcycle riding in Australia

really be that thermally stressful? Extreme Physiology \& Medicine 2015

4(Suppl 1):A20.

Submit your next manuscript to BioMed Central and take full advantage of:

- Convenient online submission

- Thorough peer review

- No space constraints or color figure charges

- Immediate publication on acceptance

- Inclusion in PubMed, CAS, Scopus and Google Scholar

- Research which is freely available for redistribution 